IP Periodica Polytechnica Chemical Engineering

61(3), pp. 188-199, 2017

https://doi.org/10.3311/PPch.10085

Creative Commons Attribution (i)

RESEARCH ARTICLE

\section{Biosorption of Fluoride from Synthetic and Ground Water Using Chlorella vulgaris Immobilized in Calcium Alginate Beads in an Upflow Packed Bed Column}

\author{
Poornima G. Hiremath ${ }^{1}$, Thomas Theodore ${ }^{1 *}$
}

Received 29 September 2016; accepted 03 January 2017

\begin{abstract}
The potential of immobilized Chlorella vulgaris to remove fluoride from synthetic and real ground water samples in a fixed bed was investigated. The effect of important kinetic parameters including column bed height, feed flow rate and influent fluoride concentration of solution on fluoride removal was studied. Thomas, Yoon-Nelson, and BDST models were used to analyze the experimental data and understand the influence on biosorption performance. The models'predictions were in good agreement with the experimental data for all the process parameters studied, indicating that the models were suitable for fixed-bed column design. Fluoride adsorption was reversible. Desorption offluoride ions was accomplished by pumping $0.1 \mathrm{~N} \mathrm{HCl}$ solution. The reusability of adsorbent was studied by subjecting column to repeated cycles of fluoride adsorption and desorption. The suitability of immobilized $C$. vulgaris adsorbent for fluoride removal from ground water samples of Pavagada taluk, Tumakuru district was studied in the packed column.
\end{abstract}

\section{Keywords}

packed-bed column, defluoridation, algae, Chlorella vulgaris, regeneration

\section{Introduction}

Water pollution by fluoride occurs either through natural or anthropogenic sources in many places of the world. Fluorine is the most electronegative element and is generally found as fluoride in most of the minerals and geochemical deposits. This fluoride enters the ground water due to geochemical reactions and volcanic emissions. The influence of human activities such as run-off and infiltration of chemical fertilizers in agricultural areas, mining, industrial chemical wastes has also increased fluoride concentration in water $[1,2]$. Fluoride concentration up to $1 \mathrm{mg} / \mathrm{L}$ promotes the development of healthy bones and formation of dental enamel. The fluoride level in drinking water exceeding $1.5 \mathrm{mg} / \mathrm{L}$ causes health related problems, mainly dental caries and skeletal fluorosis according to World Health Organization (WHO) guidelines [3]. Hence, defluoridation is a very important process to remove excess fluoride in many countries across the world including India [4, 5]. Many innovative physico-chemical processes such as precipitation, adsorption, ion exchange, electrolysis, and membrane filtration have been used for fluoride removal [6-10]. Each of these techniques is having their limitations. Ion exchange and membrane methods involve complicated preparation process of resins and membranes, respectively and are also expensive [10,11]. There is a massive toxic sludge formation in precipitation-coagulation methods [12]. Adsorption technique has been pronounced to be better fluoride removal method due to lower initial cost, flexibility, and simplicity of design, and ease of operation and maintenance [13]. Biosorption is an emerging adsorption technique that utilizes inactive/dead biological materials by way of passive uptake of ions in cellular structure, followed by subsequent binding onto active sites. A variety of algae and fungi, including Spirogyra IO2 and Spirogyra IO1, Anabaena fertilissima, Chlorococcum humicola Pleurotus ostreatus 1804 and Pleurotus eryngii ATCC 90888 have been used for the biosorption of fluoride ions [14-18]. However, most of these studies were restricted to batch studies, and not to continuous studies.

In the present study, non-living cells of algae Chlorella vulgaris immobilized in calcium alginate beads were used for fluoride removal from water in a continuous operation. C. vulgaris 
is a green, eukaryotic, unicellular alga with 2-10 $\mu \mathrm{m}$ diameter spherical microscopic cells [19]. The encapsulated dried biomass of $C$. vulgaris are widely used as a nutraceutical, as an important source of lipids for biofuel production feed, and for manufacturing highly added value components like animal feed, emulsifiers, cosmetics, pharmaceuticals, etc. [20]. So, it is completely safe to use $C$. vulgaris for water purification.

Viable and non-viable $C$. vulgaris biomass can be equally used to remove fluoride from water. However, sustaining of living biomass during adsorption is difficult due to contamination problems, and nutrients should be continuously provided. Hence, non-living algal biomass was used in the present study.

The algal powder cannot be used in the same powder form in a packed column as there can be biomass loss and may cause clogging of the column due to its small particle size, less strength and lower density. The separation of the powder algal biomass from the effluent, the regeneration, and the reuse of algal powder biosorbents also becomes tough. To avoid these problems, the algal powder was immobilized by encapsulation in a biopolymeric matrix called calcium alginate [21]. Often, immobilization of algal powder improves adsorption capacity, mechanical strength, and facilitates separation of biomass from fluoride-bearing solution [22-24].

The removal of fluoride from water by immobilized C. vulgaris under continuous flow conditions has not been previously reported. The objectives of the present work were to perform column studies to investigate the fluoride uptake characteristics of immobilized $C$. vulgaris under different flow rates, initial fluoride ion concentrations, and bed heights. Characterization of immobilized C. vulgaris before and after fluoride adsorption was carried out using FTIR and SEM. The pore size and pore area were determined by BET surface area analysis. The regeneration of calcium alginate beads was studied using $0.1 \mathrm{~N}$ $\mathrm{HCl}$ solution and distilled water. According to the data available, some places in Pavagada taluk of Tumakuru district in Karnataka contain a high concentration of fluoride $[25,26]$. Hence, a case study on fluoride removal from ground water samples collected from Pavagada region using immobilized $C$. vulgaris was conducted. The characterization of water samples was done by analyzing of water parameters.

\section{Materials and Methods}

\subsection{Chemicals and reagents}

The reagents used in the present study were of analytical grade. Sodium alginate having a viscosity (2\% aqueous solution) $>2,000 \mathrm{cP}$ was purchased from SDFCL, Mumbai, India. All preparations were done in double distilled water (DDW). A $2 \mathrm{~g}$ of sodium alginate was dissolved in $100 \mathrm{~mL} \mathrm{DDW}$ at $70^{\circ} \mathrm{C}$ with continuous stirring for $4 \mathrm{~h}$.

\subsection{Cultivation of algae and preparation of algae powder}

Chlorella vulgaris (SAG 211-11b) were procured from EPSAG, Göttingen, Germany. The algal cultures were then grown in sterilized Bold's basal media (modified) and maintained in nutrient agar at $4^{\circ} \mathrm{C}$ [27]. The composition of the growth medium and trace metal solution of $C$. vulgaris is given in Tables $1 \mathrm{a}$ and $1 \mathrm{~b}$. The cultivation was carried out in sterilized photobioreactors at $24^{\circ} \mathrm{C}$ [28]. The algal biomass obtained from cultivation was separated from the medium, dried in a hot-air oven at $70^{\circ} \mathrm{C}$ for $24 \mathrm{~h}$, pulverized to a fine powder. The dried biomass was then ground to fine powder and stored in an air-tight container.

Table 1a Composition of Bold's basal medium (modified)

\begin{tabular}{lcc}
\hline Component & $\begin{array}{c}\text { Stock solution } \\
(\mathrm{g} / \mathrm{L})\end{array}$ & $\mathrm{mL} / \mathrm{L}$ \\
\hline $\mathrm{KH}_{2} \mathrm{PO}_{4}$ & 17.5 & 10 \\
$\mathrm{CaCl}_{2} \cdot 2 \mathrm{H}_{2} \mathrm{O}$ & 2.5 & 10 \\
$\mathrm{MgSO}_{4} \cdot 7 \mathrm{H}_{2} \mathrm{O}$ & 7.5 & 10 \\
$\mathrm{NaNO}_{3}$ & 25 & 10 \\
$\mathrm{NaCl}$ & 2.5 & 10 \\
$\mathrm{Na}_{2} \mathrm{EDTA}_{2} 2 \mathrm{H} \mathrm{O}_{2}$ & 10 & 1 \\
$\mathrm{KOH}$ & 6.2 & 1 \\
$\mathrm{FeSO}_{4} \cdot 7 \mathrm{H}_{2} \mathrm{O}$ & 4.98 & 1 \\
$\mathrm{H}_{2} \mathrm{SO}_{4}$ & - & 1 \\
$\mathrm{Trace}$ metal solution & - & 1 \\
\hline
\end{tabular}

Table 1b Composition of trace metal solution

\begin{tabular}{lc}
\hline Component & Quantity $(\mathrm{g} / \mathrm{L})$ \\
\hline $\mathrm{H}_{3} \mathrm{BO}_{3}$ & 2.86 \\
$\mathrm{MnCl}_{2} \cdot 4 \mathrm{H}_{2} \mathrm{O}$ & 1.81 \\
$\mathrm{ZnSO}_{4} \cdot 7 \mathrm{H}_{2} \mathrm{O}$ & 0.222 \\
$\mathrm{Na}_{2} \mathrm{MoO}_{4} \cdot 2 \mathrm{H}_{2} \mathrm{O}$ & 0.390 \\
$\mathrm{CuSO}_{4} \cdot 5 \mathrm{H}_{2} \mathrm{O}$ & 0.079 \\
$\mathrm{Co}\left(\mathrm{NO}_{3}\right)_{2} \cdot 6 \mathrm{H}_{2} \mathrm{O}$ & 0.0494 \\
\hline
\end{tabular}

\subsection{Preparation of alginate-algae beads}

A $2 \%(w: v)$ sodium alginate solution was mixed into $1 \%$ (w:v) of C. vulgaris solution in the ratio of $1: 1$. The obtained mixture was then added drop wise through a syringe into $5 \%$ (w:v) $\mathrm{CaCl}_{2}$ solution from about $10 \mathrm{~cm}$ height. The algae-calcium alginate beads of size $2 \mathrm{~mm}$ were formed by replacement of $\mathrm{Na}^{2+}$ ions of sodium alginate by $\mathrm{Ca}^{2+}$ ions of calcium chloride solution. The beads were left in the $\mathrm{CaCl}_{2}$ solution overnight for proper cross-linking and then thoroughly washed with distilled water three times. The algae immobilized beads was in the form of small, spherical, and green particles. Samples 
were then washed several times with distilled water and dried at $70^{\circ} \mathrm{C}$ for $24 \mathrm{~h}$. Finally, samples were cooled to room temperature and transferred to airtight glass bottles ready for further investigation.

\subsection{Preparation of fluoride solution and fluoride estimation}

The stock solution of fluoride was prepared by dissolving $2.21 \mathrm{~g}$ sodium fluoride in $1000 \mathrm{~mL}$ distilled water to obtain $1000 \mathrm{mg} / \mathrm{L}$ solution. The fluoride levels were measured using ion meter and fluoride electrode (Mettler Toledo SevenCompact\# $\mathrm{pH} /$ ion meter $\mathrm{S} 220$, and perfectION ${ }^{\mathrm{TM}}$ combined fluoride electrode). Total ionic strength adjusting buffer III (TISAB - III) solution was added to the samples in the ratio of 1:10 to regulate the ionic strength of samples and standard solutions. TISAB-III maintained the solution $\mathrm{pH}$ between 5 and 5.5 , separated loosely bound fluoride ions and eliminated the interference effect of complexing ions.

\subsection{Characterization of biosorbent}

The immobilized $C$. vulgaris biosorbent was analyzed to determine its physical and chemical properties. The specific surface area and pore distributions were determined by a gravimetric nitrogen Brunauer-Emmett-Teller (BET) specific surface area analysis device (TriStar 3000 V6.05 A, US). The morphological features of the biosorbent before and after adsorption were acquired by a scanning electron microscope (SEM) (Tescan Vega 3 LMU, Czech Republic).

Fourier Transform Infrared (FTIR) spectra of the biosorbents before and after adsorption were recorded at room temperature for studying the chemical groups on the surface of the algal beads using Spectrum $\mathrm{Two}^{\mathrm{TM}}$ (Perkin-Elmer, Waltham, MA) at a resolution of $2 \mathrm{~cm}^{-1}$ in the wavenumber range of $4000-400 \mathrm{~cm}^{-1}$. A small amount of sample $(0.2 \mathrm{~g})$ was thoroughly mixed with ground $\mathrm{KBr}$ in an agate mortar, and a disc was prepared in the vacuum while maintaining a pressure of $33 \mathrm{~kg} / \mathrm{cm}^{2}$.

\subsection{Column adsorption experiments}

Column operations are essential as it provides good results, very simple to operate, less expensive and can be easily scaled up from a laboratory process.

In the present study, an acrylic column of $45 \mathrm{~cm}$ height and $2.5 \mathrm{~cm}$ internal diameter was used to conduct the column studies. The immobilized C. vulgaris was packed in the column, and the fluoride solution was pumped in up-flow direction through the bed using a peristaltic pump (Ravel pump, Model: RH-P120VS-2H) at constant inflow rate. The trials were carried out at varying flow rate $(5,7.5$ and $10 \mathrm{ml} / \mathrm{min})$, packed bed height $(2,3.2,6 \mathrm{~cm})$, and different initial fluoride solution (10, $15,25,55 \mathrm{mg} / \mathrm{L})$. The effluent solution was collected from the top of the packed column at regular intervals, and the residual fluoride concentration was measured using fluoride ion selective electrode. The operation of the column was stopped when the effluent concentration exceeded a value of $99.5 \%$ of its initial concentration.

The breakthrough curve for a column was determined by plotting the ratio of the $\mathrm{C} / \mathrm{C}_{0}\left(\mathrm{C}\right.$ and $\mathrm{C}_{0}$ are the fluoride concentration of effluent and influent, respectively) against time. The total amount of fluoride absorbed in the column material $\left(\mathrm{F}_{\mathrm{ad}}\right)$ was calculated by multiplying the area above the breakthrough curve and the flow rate. The equilibrium uptake capacity $\left(\mathrm{q}_{\mathrm{e}}\right.$, $\mathrm{mg} / \mathrm{g}$ ) of the column was obtained by dividing $\mathrm{F}_{\text {ad }}$ by the biosorbent mass (M) [22]. The percentage fluoride removal can be obtained from Eq. (1).

$$
\% \text { Removal }=\frac{\mathrm{F}_{\mathrm{ad}}}{\mathrm{C}_{\mathrm{o}} \mathrm{Qt}_{\mathrm{e}}} * 100
$$

where $\mathrm{Q}$ is the flow rate $(\mathrm{mL} / \mathrm{min}), \mathrm{t}_{\mathrm{e}}$ is the exhaustion time (min).

\section{Results and Discussion}

\subsection{Characterization of the biosorbent}

The immobilized $C$. vulgaris biosorbent was characterized using instrumental analysis. Physical properties of prepared biosorbent were summarized in Table 2. In general, the size of solute molecule adsorbing on the adsorbent surface is limited by pore volume, and the number of adsorbate molecules adsorbing is limited by the surface area of the adsorbent.

\begin{tabular}{lc} 
Table 2 Physical properties of immobilized C. vulgaris \\
\hline Properties & Results \\
\hline Pore volume, $\mathrm{cm}^{3} / \mathrm{g}$ & 0.0133 \\
Pore size, $\AA$ & 189.3036 \\
Surface area, $\mathrm{m}^{2} / \mathrm{g}$ & 2.8054 \\
Density, $\mathrm{kg} / \mathrm{m}^{3}$ & 1051.348 \\
Void fraction & 0.4688 \\
\hline
\end{tabular}

\subsubsection{FTIR studies}

FTIR spectra were obtained to determine the typical functional groups present on immobilized $C$. vulgaris that are responsible for biosorption of fluoride ions. The fluoride biosorption on the immobilized algal biomass resulted in several changes in peaks such as the shifts and decrease in the percentage of transmittance in the IR spectra of the solid surface in the range $4000-400 \mathrm{~cm}^{-1}$ as indicated in Fig. 1 and Table 3.

The FTIR spectra confirm the presence of hydroxyl, carboxyl, and amine groups on the surface of immobilized algal biomass and may be considered as significant sorption sites (Fig. 1 and Table 3). The peaks for -NH shifted slightly in the fluoride-laden biomass. This reduction in wave number may indicate the interaction of $-\mathrm{NH}_{2}$ groups of the biomass with fluoride ions. The hydrogen bonding in amines is weaker than 
Table 3 Surface functional groups observed on the immobilized C. vulgaris biosorbent before and after biosorption

\begin{tabular}{llll}
\hline $\begin{array}{l}\text { Plain calcium alginate } \\
\text { beads }\end{array}$ & \multicolumn{3}{l}{ Immobilized C. vulgaris beads } \\
\hline Before biosorption, $\mathrm{cm}^{-1}$ & Before biosorption, $\mathrm{cm}^{-1}$ & After biosorption, $\mathrm{cm}^{-1}$ & $\begin{array}{l}\text { Bands indicating } \\
\text { functional groups }\end{array}$ \\
\hline 3414 & 3410 & 3394 & $\begin{array}{l}\text { O-H stretching; } \mathrm{N}-\mathrm{H} \\
\text { stretching }\end{array}$ \\
2925 & 2922 & 2922 & C-H stretching \\
2361 & 2359 & -- & $-\mathrm{NH}_{2}$ \\
1625 & 1651 & 1640 & $\mathrm{C}=\mathrm{C}$ stretching \\
1437 & 1432 & 1425 & C-N deformation \\
1050 & 1051 & 1051 & C-O deformation \\
825 & 825 & -- & C-H deformation \\
-- & 562 & 563 & C-C skeleton \\
-- & 450 & 450 & C-C skeleton \\
\hline
\end{tabular}

that of hydroxyl groups, so $-\mathrm{NH}_{2}$ stretching bands are not as broad or intense as $-\mathrm{OH}$ stretching bands. A slight broadening of $-\mathrm{NH}_{2}$ stretching band in the fluoride biosorbed fungal biomass may be due to hydrogen bonding between the protonated amine $\left(-\mathrm{NH}_{3}^{+}\right)$and fluoride ions [18].

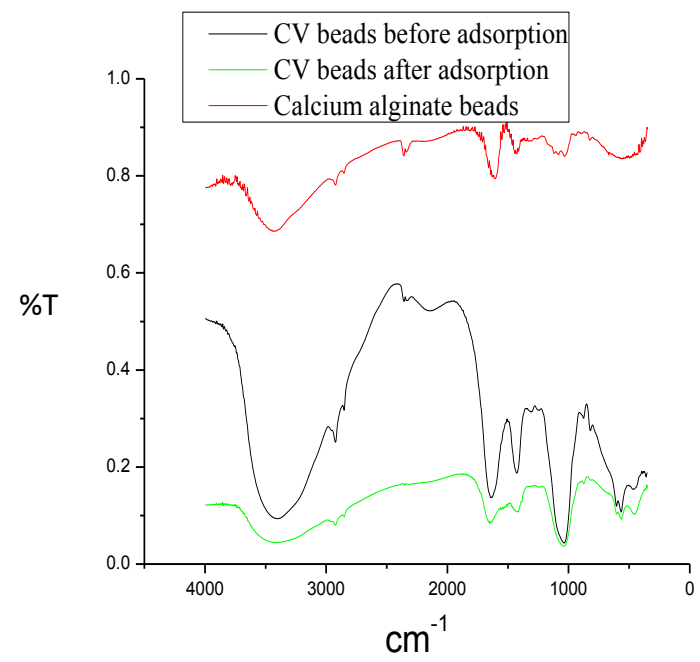

Fig. 1 FTIR spectrum of (a) plain calcium alginate beads and (b) immobilized C. vulgaris $(\mathrm{CV})$ biomass before and (c) after adsorption

\subsubsection{SEM studies}

The SEM images enable a direct observation of changes in the surface morphology of the biosorbent before and after adsorption. Fig. 2 represents the SEM images of plain calcium alginate beads and immobilized $C$. vulgaris biomass before and after fluoride adsorption.

The surface morphology of biomass, after fluoride adsorption, displays the presence of some spherical particles adhering to the surface whereas it is missing in the SEM images of beads before fluoride adsorption.

\subsection{Breakthrough curve studies}

The characteristic shape of the breakthrough curve depends on several factors including the inlet flow rates, initial solute concentration, and bed height $[29,30]$. The adsorption capacity of a packed column of fixed dimensions depends on the equilibrium relationship between solute and adsorbent, upon the transfer mechanism and the rate of adsorption [31]. The sharpness of the curve indicates not only that the system displays a linear or non-linear equilibrium isotherm, but also a rate process proportional to the solute concentration in that phase, in which the mass transfers operation is controlling. In the present study, the shape of the curve shows that adsorption is mainly controlled by mass transfer.

\subsection{Effect of initial concentration}

The effect of varying the initial fluoride concentration from 10 to $55 \mathrm{ppm}$ on the breakthrough curve, with other experimental conditions including bed height $20 \mathrm{~mm}$ and flow rate 10 $\mathrm{mL} / \mathrm{min}$ kept constant is as shown in Fig. 3 and Table 4 . The bed saturation got delayed at low initial fluoride concentration. The volume of fluoride water treated was also higher as the lower concentration gradient caused a slower transport due to decreased mass transfer coefficient. The larger the initial feed concentration, the steeper is the slope of the breakthrough curve and smaller is the breakthrough time and exhaustion time. This is due to the algal beads bed that saturates quickly leading to earlier breakthrough and exhaustion time. The results depicted in Fig. 3 confirm that the variation in the concentration gradient alters the saturation rate and breakthrough time. With the increase in feed concentration, the fluoride uptake capacity increases, but so does the driving force for mass transfer, which leads to a decrease in the adsorption zone length. 


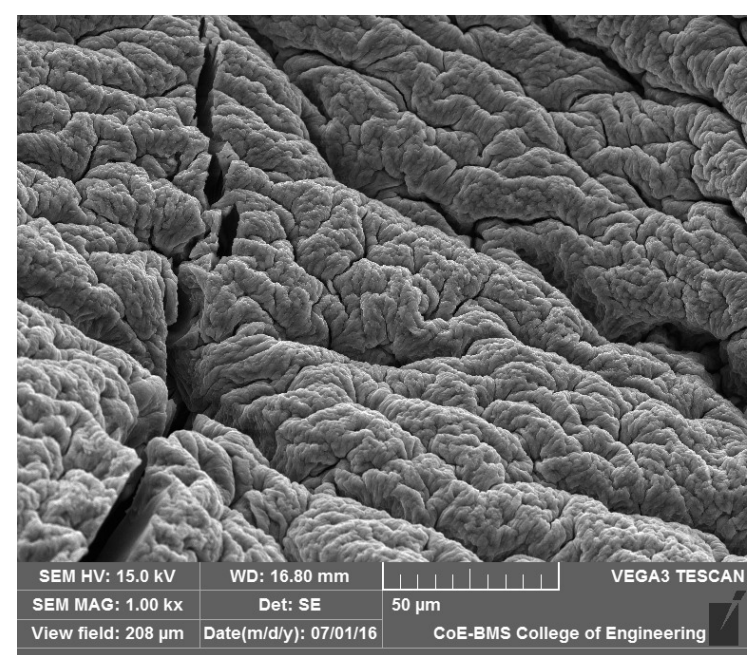

(a)

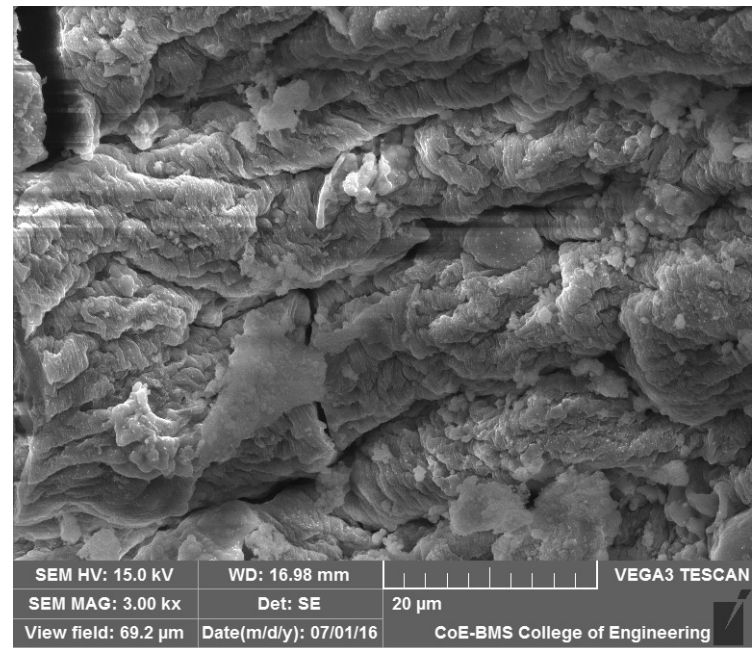

(b)

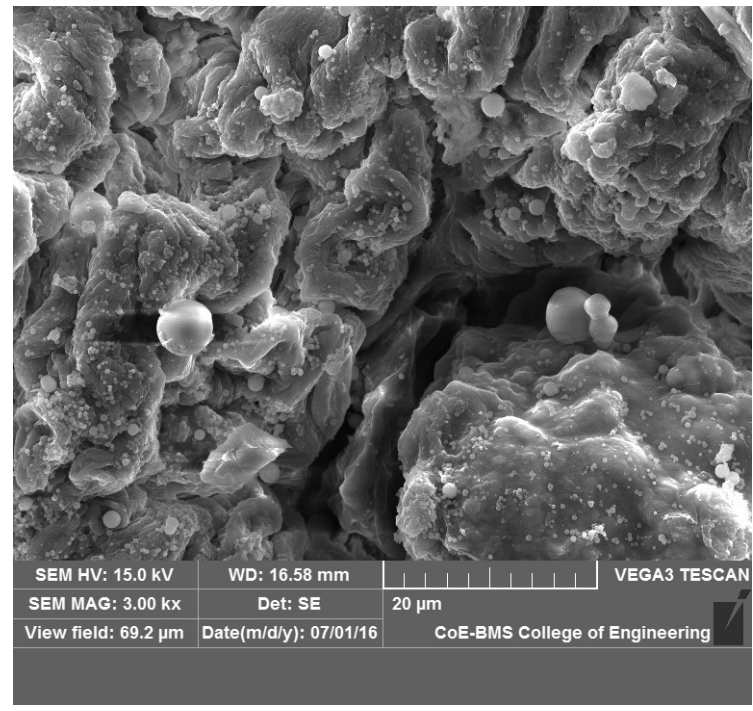

(c)

Fig. 2 SEM images of (a) plain calcium alginate beads and (b) C. vulgaris immobilized in calcium alginate beads biomass before and (c) after fluoride adsorption

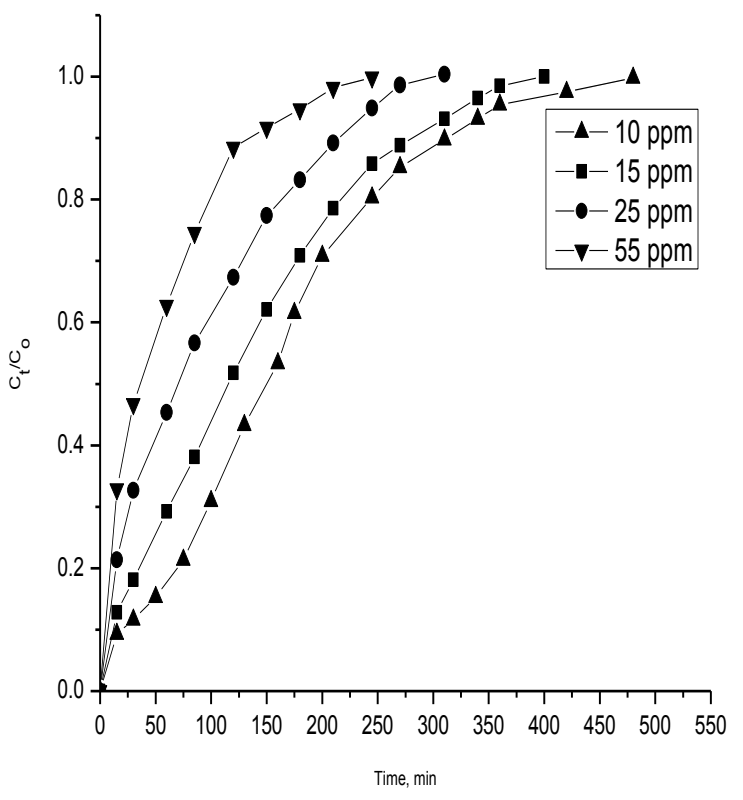

Fig. 3 Effect of initial fluoride concentration on breakthrough curve for fluoride adsorption on immobilized $C$. vulgaris beads (bed height: $20 \mathrm{~mm}$,

flow rate: $5 \mathrm{ml} / \mathrm{min}$ )

Table 4 Column sorption data obtained during biosorption on to immobilized C. vulgaris beads at different initial fluoride concentration $(\mathrm{pH}-7.45$, bed height $-20 \mathrm{~mm}$, flow rate $-5 \mathrm{~mL} / \mathrm{min}$ )

\begin{tabular}{lccc}
\hline $\begin{array}{l}\text { Initial fluoride } \\
\text { concentration } \\
(\mathrm{ppm})\end{array}$ & $\begin{array}{c}\mathrm{t}_{\mathrm{b}} \\
(\mathrm{min})\end{array}$ & $\begin{array}{c}\mathrm{t}_{\mathrm{e}} \\
(\mathrm{min})\end{array}$ & $\begin{array}{c}\text { Removal of } \\
\text { fluoride }(\%)\end{array}$ \\
\hline 55 & 3 & 245 & 0.423 \\
25 & 12 & 310 & 1.200 \\
15 & 18 & 400 & 2.200 \\
10 & 27 & 480 & 3.313 \\
\hline
\end{tabular}

\subsection{Effect of flow rate}

The breakthrough curve of fluoride biosorption by C. vulgaris immobilized in calcium alginate beads was investigated by maintaining initial fluoride concentration at $10 \mathrm{ppm}$ and bed height at $32 \mathrm{~mm}$ constant and varying the flow rate from 5 to $20 \mathrm{~mL} / \mathrm{min}$ (Table 5). The column performed well at the lowest flow rate. Initially, the adsorption was very rapid at lower flow rates probably associated with the availability of biosorption sites to capture fluoride around or inside the beads. In the next stage of the process due to the gradual occupancy of these sites, the uptake becomes less effective. At higher flow rates, the residence time of ion solutions in the column will not be sufficient to establish equilibrium. Hence, an early breakthrough and exhaustion time was observed which resulted in steeper breakthrough curves and shortening of the mass transfer zone (Fig. 4). The column performed well at $5 \mathrm{~mL} / \mathrm{min}$. Hence, this flow rate was maintained for further studies. The results are depicted in Fig. 4. 


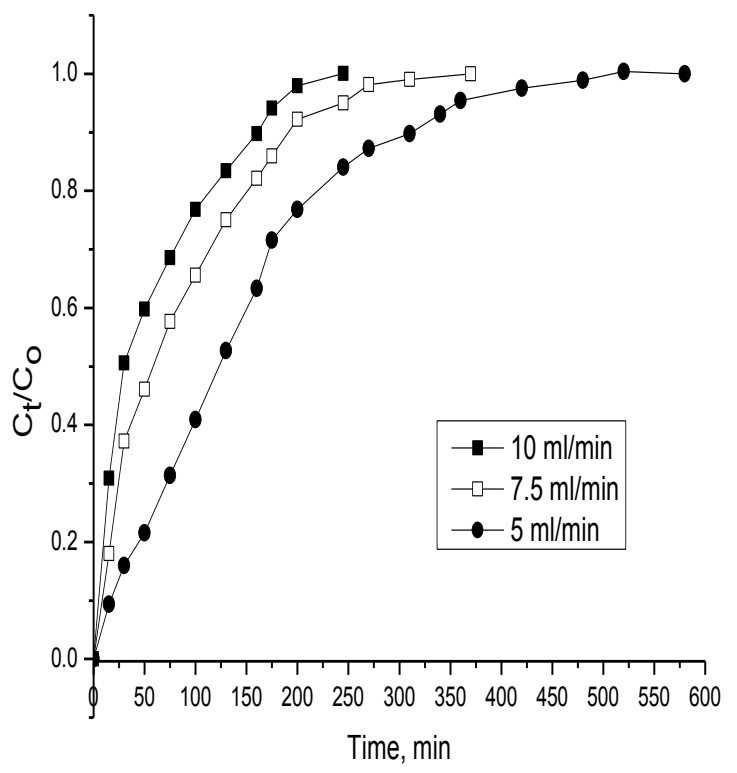

Fig. 4 Effect of flow rate on breakthrough curve for $\mathrm{F}^{-}$adsorption on immobilized C. vulgaris beads ( $\mathrm{pH}-7.45$, bed height $-32 \mathrm{~mm}$, feed concentration - $10 \mathrm{ppm})$

Table 5 Column sorption data obtained during biosorption on to immobilized C. vulgaris beads at different flow rates $(\mathrm{pH}-7.45$, bed height $-32 \mathrm{~mm}$, feed concentration $-10 \mathrm{ppm}$ )

\begin{tabular}{lccc}
\hline $\begin{array}{l}\text { Flow rate } \\
(\mathrm{mL} / \mathrm{min})\end{array}$ & $\begin{array}{c}\mathrm{t}_{\mathrm{b}} \\
(\mathrm{min})\end{array}$ & $\begin{array}{c}\mathrm{t}_{\mathrm{e}} \\
(\mathrm{min})\end{array}$ & $\begin{array}{c}\text { Removal of } \\
\text { fluoride }(\%)\end{array}$ \\
\hline 5 & 30 & 520 & 2.69 \\
7.5 & 15 & 310 & 2.58 \\
10 & 10 & 245 & 2.45 \\
\hline
\end{tabular}

\subsection{Effect of bed height}

The experiments were conducted at a constant feed concentration of $10 \mathrm{ppm}$, a flow rate of $5 \mathrm{~mL} / \mathrm{min}$, with bed height ranging from 20 to $60 \mathrm{~mm}$. The effect of bed height for the adsorption of fluoride is shown in Fig. 5. The results reveal that both breakthrough time and exhaustion time increased with increase in bed height. This is due to the increase in binding sites that are available for sorption. The increased bed height also resulted in a broadened mass transfer zone. Table 6 depicted the results of the effect of bed height.

Table 6 Column sorption data obtained during biosorption on to immobilized C. vulgaris beads at different bed heights $(\mathrm{pH}-7.45$, feed concentration -10 ppm, flow rate- $5 \mathrm{~mL} / \mathrm{min}$ )

\begin{tabular}{lccc}
\hline $\begin{array}{l}\text { Bed height } \\
(\mathrm{mm})\end{array}$ & $\begin{array}{c}\mathrm{t}_{\mathrm{b}} \\
(\mathrm{min})\end{array}$ & $\begin{array}{c}\mathrm{t}_{\mathrm{e}} \\
(\mathrm{min})\end{array}$ & $\begin{array}{c}\text { Removal of } \\
\text { fluoride }(\%)\end{array}$ \\
\hline 60 & 135 & 720 & 4.51 \\
32 & 90 & 600 & 4.16 \\
20 & 60 & 440 & 3.97 \\
\hline
\end{tabular}

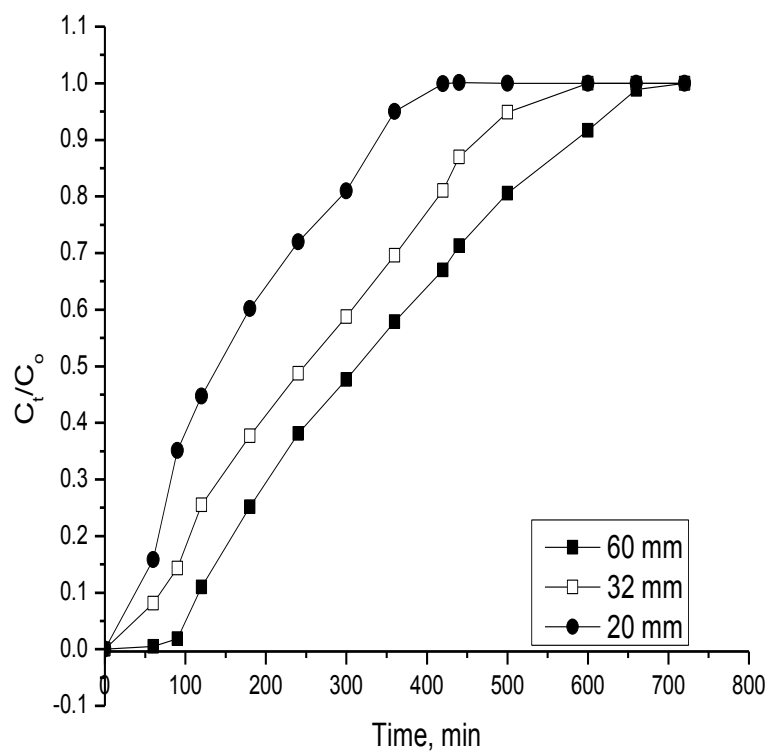

Fig. 5 Effect of bed height on breakthrough curve for $\mathrm{F}^{-}$adsorption on immobilized C. vulgaris beads (feed concentration - $\mathrm{pH}-7.45,10 \mathrm{ppm}$, flow rate: $5 \mathrm{ml} / \mathrm{min}$ )

\subsection{Thomas Model}

Among the various mathematical models available to describe the fixed bed adsorption, Thomas model is most simple and widely used by several investigators [32, 33]. This model is based on the mass transfer model which assumes that fluoride ion migrates from the solution to the liquid film around the adsorbent and diffuses through the film to the surface of the adsorbent. This is followed by intra-particle diffusion and adsorption on the active site. Eq. (2) expresses the linearized form of Thomas model.

$$
\mathrm{k}_{\mathrm{T}}\left(\frac{\mathrm{Q}_{\mathrm{o}} \mathrm{M}}{\mathrm{r}}-\mathrm{C}_{\mathrm{o}} \mathrm{t}\right)=\ln \left(\frac{\mathrm{C}_{\mathrm{o}}}{\mathrm{C}}-1\right)
$$

where $\mathrm{k}_{\mathrm{T}}$ is the Thomas model constant ( $\left.\mathrm{mL} / \mathrm{mg} / \mathrm{min}\right), \mathrm{Q}_{\mathrm{o}}$ is the maximum solid phase concentration of solute $(\mathrm{mg} / \mathrm{g}), \mathrm{M}$ is the mass of adsorbent in the column $(\mathrm{g}), \mathrm{r}$ is the flow rate $(\mathrm{mL} / \mathrm{min}), \mathrm{C}_{\mathrm{o}}$ is the initial fluoride concentration $(\mathrm{mg} / \mathrm{L})$ and $\mathrm{C}$ is the effluent fluoride concentration $(\mathrm{mg} / \mathrm{L})$ at any time $\mathrm{t}(\mathrm{min})$. The model constants $\mathrm{k}_{\mathrm{T}}$ and $\mathrm{Q}_{\mathrm{o}}$ were calculated from a plot of $\ln \left[\left(\mathrm{C} / \mathrm{C}_{\mathrm{o}}\right)-1\right]$ against $\mathrm{t}$ at a given flow rate [32]. The Thomas model provided a good fit to the experimental data, at all the flow rates examined, with correlation coefficients greater than 0.94, which would indicate the external and internal diffusions were not the rate limiting step [22]. The rate constant $\left(\mathrm{k}_{\mathrm{T}}\right)$ increased with increasing flow rate which suggests that the mass transport resistance decreases. The concentration difference of fluoride between algal biomass and aqueous solution reason is the main driving force for adsorption [22]. The comparison of the experimental points and predicted curves according to the Thomas model is also shown in Figs. 6-8 at different experimental conditions. Table 7 depicted the column kinetic constants for fluoride removal by $C$. vulgaris beads. 
Table 7 Column kinetic constants for fluoride removal by C. vulgaris

\begin{tabular}{lccccccccc}
\hline \multirow{2}{*}{ Column kinetic model } & \multicolumn{3}{c}{ Flow rates } & \multicolumn{3}{c}{ Bed height } & \multicolumn{3}{c}{ Initial fluoride concentration } \\
\cline { 2 - 10 } & $5 \mathrm{~mL} / \mathrm{min}$ & $7.5 \mathrm{~mL} / \mathrm{min}$ & $10 \mathrm{~mL} / \mathrm{min}$ & $60 \mathrm{~mm}$ & $32 \mathrm{~mm}$ & $20 \mathrm{~mm}$ & $55 \mathrm{ppm}$ & $25 \mathrm{ppm}$ & $15 \mathrm{ppm}$ \\
\hline Thomas & 1.359 & 1.876 & 2.038 & 1.273 & 1.056 & 1.311 & 0.239 & 0.746 & 1.450 \\
\hline $\mathrm{k}_{\mathrm{T}}(\mathrm{mL} / \mathrm{mg} / \mathrm{min})$ & 0.683 & 0.528 & 0.387 & 0.717 & 0.884 & 0.814 & 2.182 & 0.476 & 0.179 \\
$\mathrm{Q}_{\mathrm{o}}(\mathrm{mg} / \mathrm{g})$ & 0.982 & 0.982 & 0.928 & 0.9 & 0.97 & 0.95 & 0.957 & 0.973 & 0.982 \\
$\mathrm{R}^{2}$ & & & & & & & & & \\
\hline Yoon-Nelson & 0.014 & 0.019 & 0.020 & 0.011 & 0.011 & 0.013 & 0.013 & 0.019 & 0.027 \\
\hline $\mathrm{k}_{\mathrm{YN}}(1 / \mathrm{min})$ & 136.67 & 70.39 & 38.745 & 335.17 & 255.53 & 157.37 & 115.04 & 55.19 & 42.71 \\
$\tau(\min )$ & 0.982 & 0.982 & 0.928 & 0.917 & 0.971 & 0.947 & 0.957 & 0.973 & 0.905 \\
$\mathrm{R}^{2}$ & & & & & & & & &
\end{tabular}

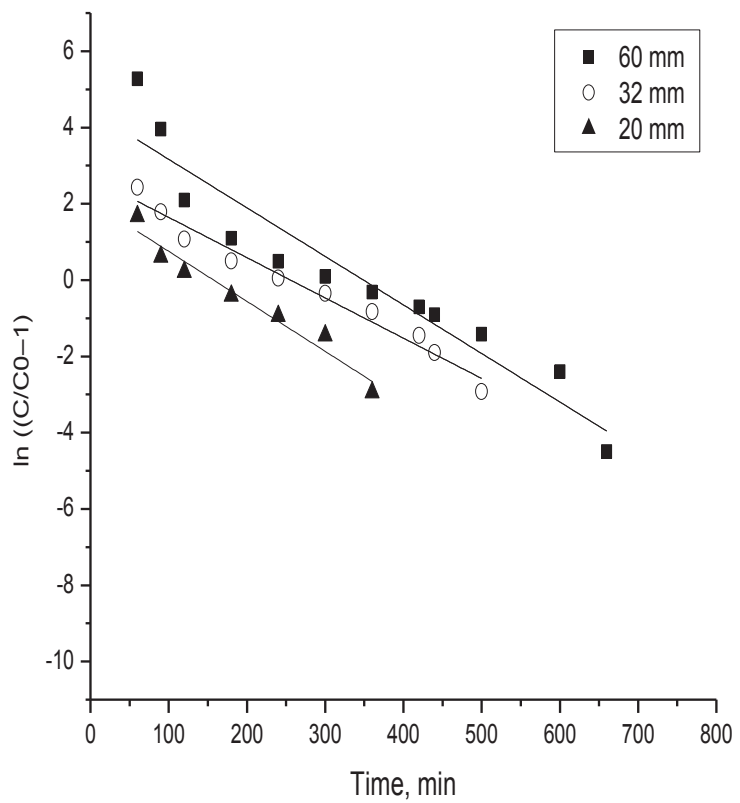

Fig. 6 Thomas model plot for fluoride removal by C. vulgaris beads: Effect of bed height

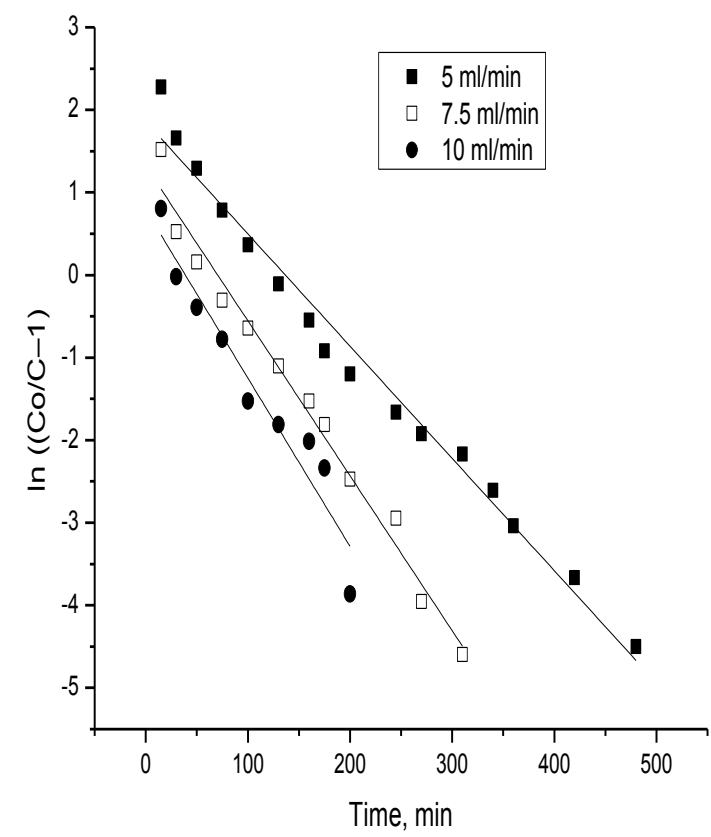

Fig. 7 Thomas model plot for fluoride removal by C. vulgaris beads: Effect of flow rate

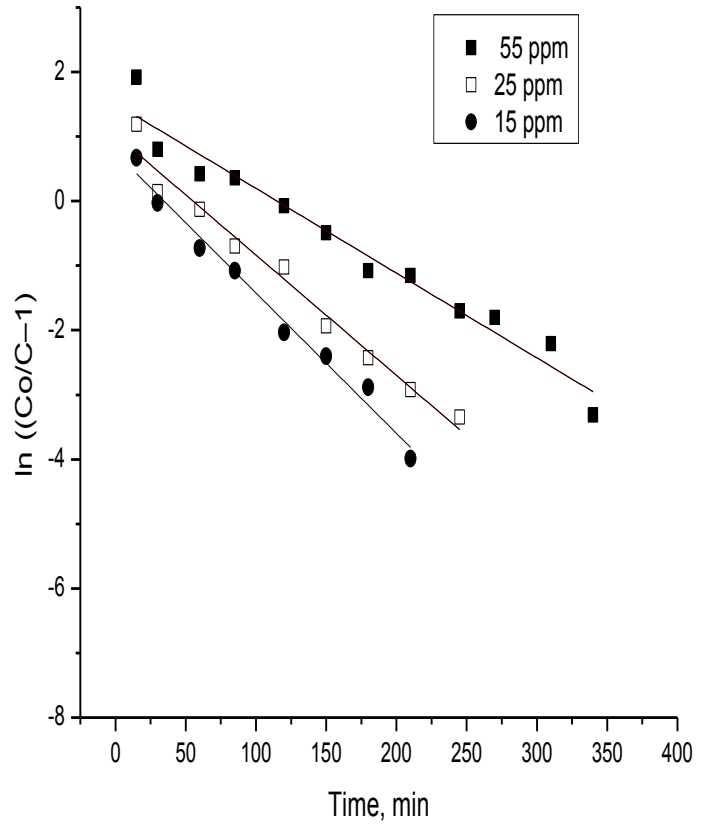

Fig. 8 Thomas model plot for fluoride removal by $C$. vulgaris beads: Effect of initial fluoride concentration

\subsection{Yoon-Nelson Model}

The simple theoretical Yoon-Nelson model was applied to consider the breakthrough behavior of fluoride on algal beads. The Yoon-Nelson model was proposed based on the hypothesis that the rate of reduction in the probability of adsorption for each solute molecule is equivalent to the probability of solute adsorption and the probability of solute breakthrough on the adsorbent [34]. This model is less complicated than other models, and does not need detailed information about the characteristics of solute, the type of adsorbent, and the physical properties of the adsorption bed [34]. The linearized form of the Yoon-Nelson equation for a single component system is expressed in Eq. (3) [22].

$$
\ln \left(\frac{C}{\mathrm{C}_{\mathrm{o}}-\mathrm{C}}\right)=k_{\mathrm{YN}} \cdot t-\tau \cdot k_{\mathrm{YN}}
$$

where $\tau$ is the time required for $50 \%$ adsorbate breakthrough $(\mathrm{min}), \mathrm{k}_{\mathrm{YN}}$ is the rate constant $(\mathrm{L} / \mathrm{min})$, and $\mathrm{t}$ is the breakthrough (sampling) time (min). A plot of $\ln \left(\frac{\mathrm{C}}{\mathrm{C}_{0}-\mathrm{C}}\right)$ vs. $\mathrm{t}$ gives a straight line with a slope of and intercept of $-\tau$. $\mathrm{k}_{\mathrm{YN}}$. 
The values of $\mathrm{k}_{\mathrm{YN}}$ and $\tau$ are listed in Table 7. As seen in Table 7 , the rate constant increased and the $50 \%$ breakthrough time $\tau$ decreased with both increasing flow rate and influent fluoride concentration. The comparison of the experimental points and predicted curves according to the Yoon-Nelson model is shown in Figs. 9-11 at different experimental conditions. The experimental breakthrough curves were close to those predicted by the Yoon-Nelson model.

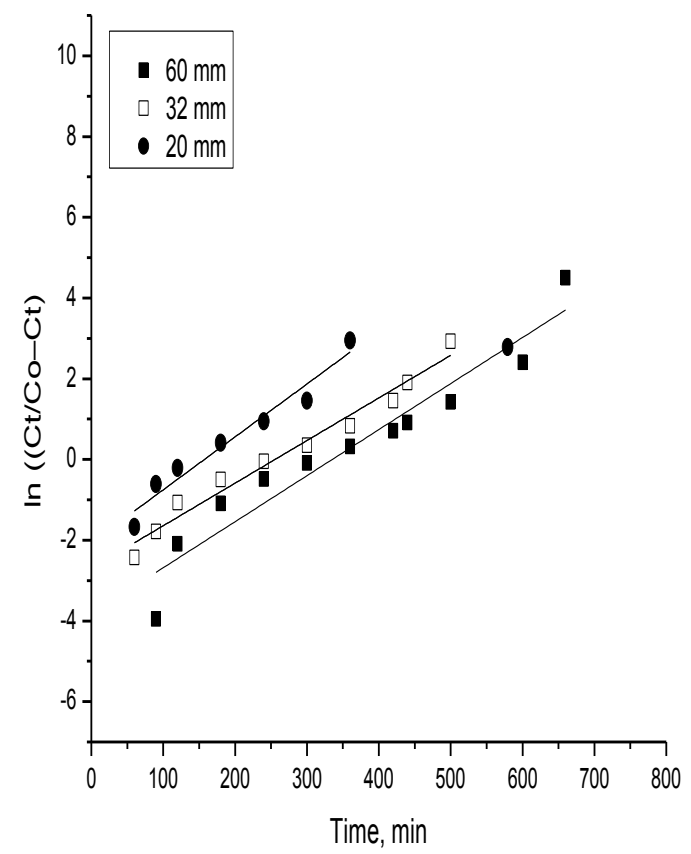

Fig. 9 Yoon-Nelson model plot for fluoride removal by C. vulgaris beads: Effect of bed height

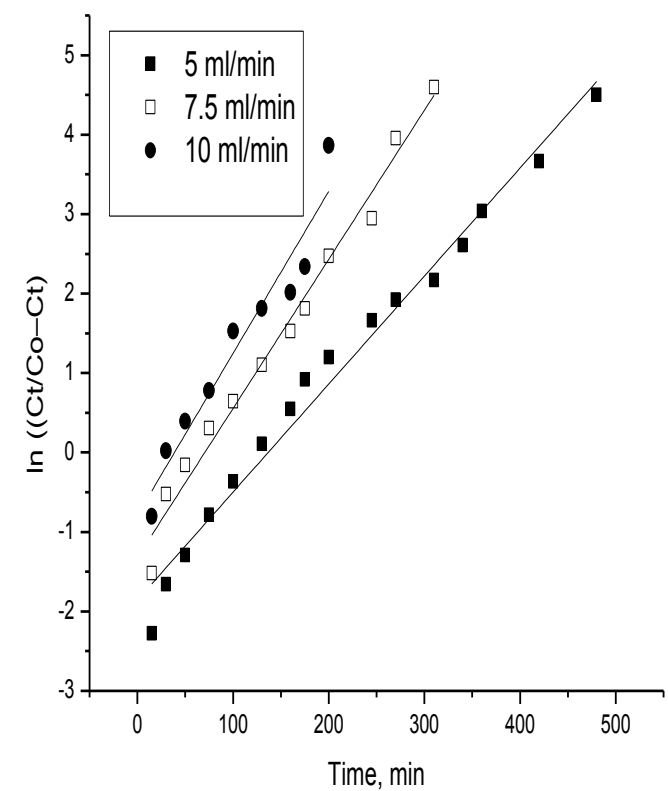

Fig. 10 Yoon-Nelson model plot for fluoride removal by C. vulgaris beads: Effect of flow rate

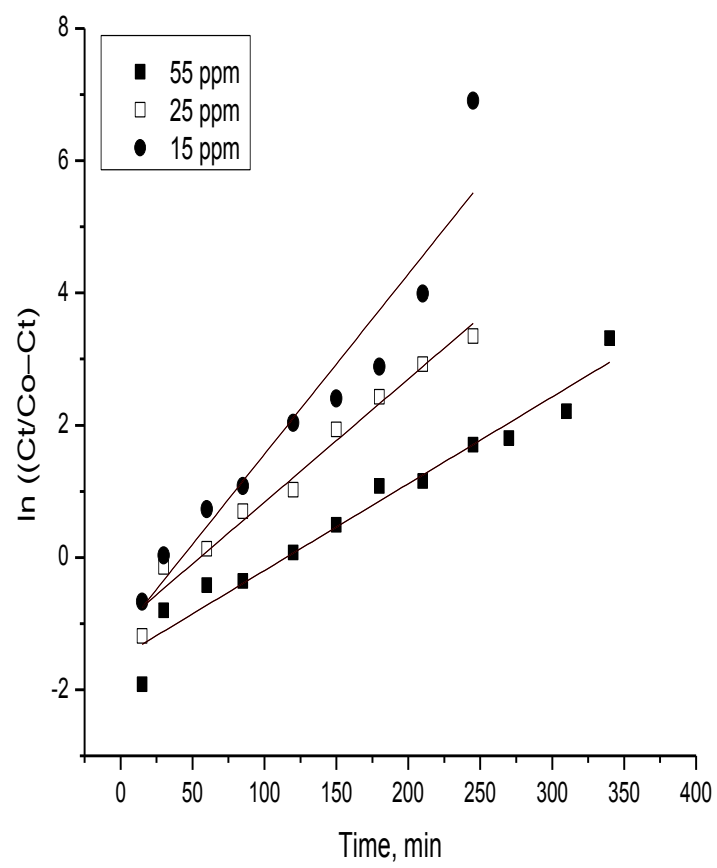

Fig. 11 Yoon-Nelson model plot for fluoride removal by $C$. vulgaris beads: Effect of initial fluoride concentration

\subsection{Bed depth service time (BDST) model}

The BDST model is used for predicting how long the adsorbent would be able to sustain the removal of a specified amount of adsorbate from solution before the actual regeneration or replacement is required. The model works based on a relation between the service time of the column and the depth of packed bed column. Bohart and Adams developed a relationship between the bed depth, Z, and the service time, $t$ [35]. However, Hutchins has extended it to a linear relation between the bed depth $(Z)$ and the service time (T) of the form presented in Eq. (4) [36].

$$
\mathrm{T}=\frac{\mathrm{N}_{\mathrm{o}}}{\mathrm{C}_{\mathrm{o}} v} \mathrm{Z}-\frac{1}{\mathrm{~K}_{\mathrm{a}} \mathrm{C}_{\mathrm{o}}} \ln \left(\frac{\mathrm{C}_{\mathrm{o}}}{\mathrm{C}}-1\right)
$$

where $\mathrm{T}=$ service time at breakthrough point $(\mathrm{h}) ; \mathrm{C}=$ effluent concentration of solute in the liquid phase $(\mathrm{mg} / \mathrm{l}) ; \mathrm{C}_{\mathrm{o}}=$ initial concentration of solute in the liquid phase $(\mathrm{mg} / \mathrm{l}) ; \mathrm{v}=$ linear flow rate through the bed $(\mathrm{cm} / \mathrm{h}) ; \mathrm{N}_{\mathrm{o}}=$ the bed capacity $\left(\mathrm{mg} / \mathrm{cm}^{3}\right)$; $\mathrm{K}_{\mathrm{a}}=$ rate constant in $\operatorname{BDST}$ model $\left(\mathrm{cm}^{3} / \mathrm{mg}-\mathrm{h}\right)$; and $\mathrm{Z}=$ bed depth of column $(\mathrm{cm})$. The column service time was selected as the time when the normalized concentration, $\mathrm{C} / \mathrm{C}_{\mathrm{o}}$ reached 0.05 . A plot of service time versus bed depth, at a flow rate of $5 \mathrm{~mL} / \mathrm{min}$ (Fig. 12) was linear. The service time at different bed depths is depicted in Table 8. The high correlation coefficient value $\left(\mathrm{R}^{2}=0.987\right)$ indicated the validity of the BDST model for the present system. The values of $\mathrm{N}_{\mathrm{o}}$ and $\mathrm{K}_{\mathrm{a}}$ were evaluated from the slope $\left(\mathrm{N}_{\mathrm{o}} / \mathrm{C}_{\mathrm{o}} v\right)$ and intercept $\left(\frac{1}{\mathrm{~K}_{\mathrm{a}} \mathrm{C}_{\mathrm{o}}} \ln \left(\frac{\mathrm{C}_{\mathrm{o}}}{\mathrm{C}}-1\right)\right)$ of the BDST plot. The values of BDST model parameters are presented in Table 9. The value of $\mathrm{K}_{\mathrm{a}}$ characterizes the rate of transfer from the fluid phase to the solid phase. If $\mathrm{K}_{\mathrm{a}}$ is large, even a short bed will avoid breakthrough, but as $\mathrm{K}_{\mathrm{a}}$ decreases 
a progressively deeper bed is required to avoid breakthrough. The slope of the BDST line represents the time required for the adsorption zone to travel a unit length through the adsorbent and used to predict the performance of the bed, if there is a change in the initial solute concentration, $\mathrm{C}_{0}$, to a new value of solute concentration [37]. It is used to predict the performance of the bed. The critical bed depth $\left(\mathrm{H}_{\mathrm{o}}\right)$ is the theoretical depth of adsorbent adequate to assure that the outlet solute concentration does not surpass the breakthrough concentration $\left(\mathrm{C}_{\mathrm{b}}\right)$ value at time $\mathrm{t}=0 . \mathrm{H}_{\mathrm{o}}$ can be calculated as Eq. (5) [38]. The line of the best fit for the plot is obtained by the method of least squares as shown in Eq. (6). The obtained graph is shown in Fig. 12.

$$
\mathrm{H}_{\mathrm{o}}=\frac{v}{\mathrm{~N}_{\mathrm{o}} \mathrm{K}_{\mathrm{a}}} \ln \left(\frac{\mathrm{C}_{\mathrm{o}}}{\mathrm{C}}-1\right)
$$

The equation of fitted line is found to be:

$$
\mathrm{T}=0.3046 \mathrm{Z}+0.4462
$$

The value of $\mathrm{R}^{2}$ for the best fit line is found to be 0.9875 .

Table 8 Service Time at Different Bed Depths

\begin{tabular}{lcc}
\hline Sl. No. & Bed depth, Z, (cm) & Service time, T, (h) \\
\hline 1 & 6 & 2.25 \\
2 & 3.2 & 1.50 \\
3 & 2 & 1.00 \\
\hline
\end{tabular}

Table 9 BDST parameters for $5 \mathrm{~mL} / \mathrm{min}$ flow rate

\begin{tabular}{ccc}
\hline $\mathrm{N}_{\mathrm{o}},\left(\mathrm{mg} / \mathrm{cm}^{3}\right)$ & $\mathrm{K}_{\mathrm{a}},\left(\mathrm{cm}^{3} / \mathrm{mg}-\mathrm{h}\right)$ & $\mathrm{H}_{\mathrm{o}},(\mathrm{cm})$ \\
\hline 1.14 & 0.38 & 75.76 \\
\hline
\end{tabular}

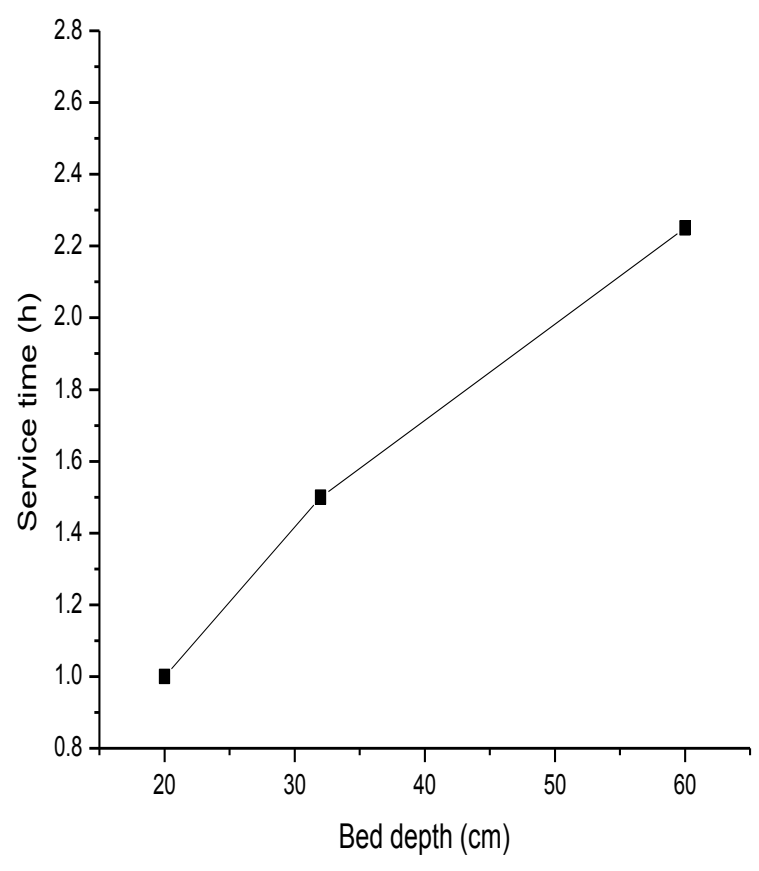

Fig. 12 BDST Plot for flow rate of $5 \mathrm{ml} / \mathrm{min}$

\subsection{Regeneration and Reuse of Biomass}

To make the biosorption-based process feasible for industrial application, provision needs to be done to regenerate the biomass for repeated use. Fluoride sorbed on biomass can be desorbed by a suitable eluant or desorbing solution, and thus biomass can be used in multiple sorption-desorption cycles. C. vulgaris cells immobilized in alginate beads was regenerated using $0.1 \mathrm{M} \mathrm{HCl}$ at a flow rate of $5 \mathrm{~mL} / \mathrm{min}$. The desorbing solution was passed through the column, and the effluent fluoride concentration was recorded at regular intervals. The flow of desorbing solution was stopped when the effluent concentration of fluoride reduced to zero. Distilled water was then passed through the column until the effluent $\mathrm{pH}$ approached 7 . The regenerated bed was reused for next cycle. The experiments were conducted for 4 cycles. The breakthrough and exhaustion time were reduced progressively with increase in the number of cycles due to deterioration of bed. The results are depicted in Fig. 13 and Table 10 with four regeneration cycles. The percentage removal reduced by $22 \%$ to $35.7 \%$ after the cycle I and reduced by $27 \%$ by the end of cycle IV. Furthermore, relatively effective reusability was noticed when the loaded biomass was desorbed with $5 \mathrm{M} \mathrm{HCl}$ solution.

Table 10 Effect of regeneration of immobilized C. vulgaris beads on fluoride removal

\begin{tabular}{lcccc}
\hline Cycle & $\mathrm{t}_{\mathrm{e}}$ & $\mathrm{F}_{\mathrm{ad}}$ & $\mathrm{C}_{\mathrm{o}} \mathrm{Qt}_{\mathrm{e}}$ & \% Removal $=\mathrm{F}_{\mathrm{ad}} / \mathrm{C}_{\mathrm{o}} \mathrm{Qt}_{\mathrm{e}}$ \\
\hline 1 & 720 & 16500 & 36000 & 45.833 \\
2 & 420 & 7500 & 21000 & 35.714 \\
3 & 260 & 4375 & 13000 & 33.654 \\
4 & 180 & 3000 & 9000 & 33.333 \\
\hline
\end{tabular}

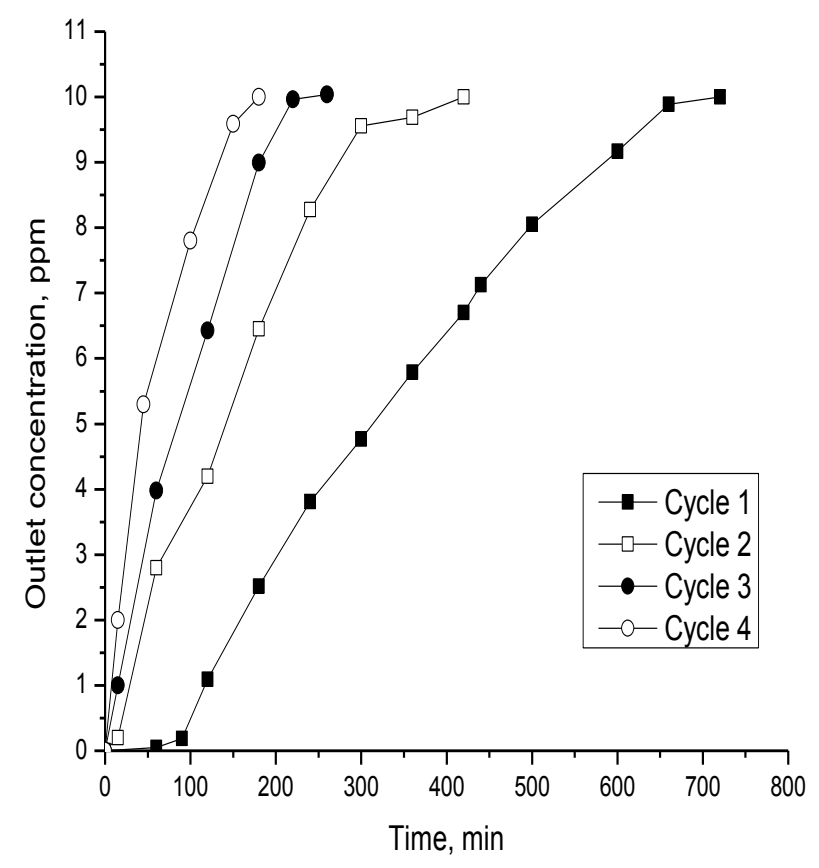

Fig. 13 Effect of regeneration of immobilized C. vulgaris beads for defluoridation using $0.1 \mathrm{M} \mathrm{HCl}$, water $(\mathrm{pH}-7.45$, bed height: $6 \mathrm{~cm}$ feed concentration: $10 \mathrm{mg} / \mathrm{L}$ flow rate: $5 \mathrm{~mL} / \mathrm{min}$ ) 
Table 11 Chemical characteristics of raw and treated water from Pavagada taluk, Tumakuru District, Karnataka state

\begin{tabular}{|c|c|c|c|c|c|c|c|c|}
\hline \multirow{2}{*}{$\begin{array}{l}\text { Village name } \\
\text { Parameters }\end{array}$} & \multicolumn{2}{|c|}{ Veeralakondi } & \multicolumn{2}{|c|}{ Thimapura } & \multicolumn{2}{|c|}{ Palavalli } & \multicolumn{2}{|c|}{ Bommathnahalli } \\
\hline & $\begin{array}{c}\text { Influent } \\
\text { water }\end{array}$ & $\begin{array}{l}\text { Treated } \\
\text { water }\end{array}$ & $\begin{array}{l}\text { Influent } \\
\text { water }\end{array}$ & $\begin{array}{l}\text { Treated } \\
\text { water }\end{array}$ & $\begin{array}{l}\text { Influent } \\
\text { water }\end{array}$ & $\begin{array}{l}\text { Treated } \\
\text { water }\end{array}$ & $\begin{array}{l}\text { Influent } \\
\text { water }\end{array}$ & $\begin{array}{c}\text { Treated } \\
\text { water }\end{array}$ \\
\hline Fluoride & 2.606 & 1.224 & 3.685 & 1.345 & 4.678 & 1.598 & 2.662 & 1.212 \\
\hline Calcium & 88.8 & 23.6 & 85.62 & 44 & 183.06 & 156 & 99.24 & 55.62 \\
\hline Total Hardness & 264 & 252 & 152 & 140 & 276 & 164 & 352 & 258 \\
\hline $\mathrm{pH}$ & 7.28 & 7.82 & 7.78 & 7.9 & 7.95 & 8.13 & 6.91 & 6.96 \\
\hline Iron & 0.02 & 0.15 & 0.01 & 0.07 & 0 & 0.42 & 0 & 0.32 \\
\hline Sulphate & 28 & 28 & 27 & 29 & 17 & 27 & 32 & 34 \\
\hline Chloride & 109.96 & 10.99 & 41.986 & 11.22 & 21.99 & 12.32 & 597.8 & 180 \\
\hline Nitrate & 28 & 32 & 160 & 211 & 32 & 45 & 34 & 48 \\
\hline
\end{tabular}

Note: All parameters are expressed in $\mathrm{mg} / \mathrm{L}$, except $\mathrm{pH}$.

\subsection{Case study - Treatment of fluoride contaminated Pavagada ground water in column mode}

The case study on treatment of fluoride contaminated ground water of Pavagada taluk, Tumakuru district using C. vulgaris cells immobilized in alginate beads as biosorbent were conducted in packed column. The suitability of adsorbent for fluoride removal was found by performing experiments using $25 \mathrm{~g}$ of biosorbent. The fluoride contaminated water was sent up-flow through the column at a flow rate of $5 \mathrm{~mL} / \mathrm{min}$. Each lot volume of $100 \mathrm{~mL}$ were individually collected and analyzed for fluoride content. The adsorption capacity was calculated once the fluoride level exceeded $1.5 \mathrm{mg} / \mathrm{L}$. Case study on characteristics of ground water of Pavagada was successfully done and results are depicted in Table 11 using $C$. vulgaris immobilized in calcium alginate beads as biosorbents.

\section{Conclusions}

Immobilized C. vulgaris in calcium alginate beads performed well for the fluoride biosorption during packed bed column studies. The optimum conditions for biosorption were determined as: flow rate of feed to column $=5 \mathrm{~mL} / \mathrm{min}$, the initial concentration of fluoride $=10 \mathrm{mg} / \mathrm{L}$ and the bed height of biosorbent $=6 \mathrm{~cm}$. Calcium alginate beads were regenerated using $0.1 \mathrm{M} \mathrm{HCl}$ solution and four adsorption-desorption cycles were conducted. After four cycles, beads were broken and the percentage removal reduced from $46 \%$ to $33 \%$. From FT-IR spectral analysis and SEM textures of beads before and after fluoride biosorption, confirmed that non-living biomass of $C$. vulgaris is suitable biosorbent for fluoride removal. The immobilized C. vulgaris adsorbent was found good in treating ground water samples of Pavagada taluk, Tumakuru district during packed column studies.

\section{Acknowledgement}

The authors are thankful to the Principal and Management of Siddaganga Institute of Technology, Tumkur- 572103, Karnataka, India for their constant support and encouragement.

\section{Supplemental Information}

The batch experiments were conducted wherein the empty calcium alginate beads were used and the uptake capacity was found to be $0.583 \mathrm{mg} / \mathrm{g}$. Similar results were obtained by Pandi and Viswanathan (2014) wherein the defluoridation capacity of calcium alginate beads were observed to be $0.680 \mathrm{mg} / \mathrm{g}$.

Reference: TK. Pandi, and N. Viswanathan, "Synthesis of alginate bioencapsulated nano-hydroxyapatitecomposite for selective fluoride sorption," Carbohydr. Polym., vol. 112, pp. 662-667, Nov. 2014.

\section{References}

[1] Islam, M., Patel, R. "Evaluation of removal efficiency of fluoride from aqueous solution using quick lime." Journal of Hazardous Materials. 143(1), pp. 303-310. 2007.

https://doi.org/10.1016/j.jhazmat.2006.09.030

[2] Saxena, V., Ahmed, S. "Inferring the chemical parameters for the dissolution of fluoride in groundwater." Environmental Geology. 43(6), pp. 731-736. 2003.

https://doi.org/10.1007/s00254-002-0672-2

[3] WHO 2008. Guidelines for Drinking - Water Quality, 3rd Ed., Incorporating the first and second addenda, Vol. 1, World Health Organization (WHO): Geneva, Switzerland: WHO Press. http://www.who.int/water sanitation_health/dwq/fulltext.pdf

[4] Mameri, N., Yeddou, A., Lounici, H., Belhocine, D., Grib, H., Bariou, B. "Defluoridation of septentrional Sahara water of North Africa by electrocoagulation process using bipolar aluminium electrodes." Water Research. 32(5), pp. 1604-1612. 1998. https://doi.org/10.1016/S0043-1354(97)00357-6

[5] Susheela, A. "Fluorosis management programme in India." Current Science-Bangalore. 7. pp. 1250-1256. 1999. 
[6] Saha, S. "Treatment of aqueous effluent for fluoride removal." Water Research. 27(8), pp. 1347-1350. 1993.

https://doi.org/10.1016/0043-1354(93)90222-4

[7] Ghorai, S., Pant, K. "Investigations on the column performance of fluoride adsorption by activated alumina in a fixed-bed." Chemical Engineering Journal. 98(1), pp. 165-173. 2004. https://doi.org/10.1016/j.cej.2003.07.003

[8] Vaaramaa, K., Lehto, J. "Removal of metals and anions from drinking water by ion exchange." Desalination. 155(2), pp. 157-170. 2003. https://doi.org/10.1016/S0011-9164(03)00293-5

[9] Amor, Z., Bariou, B., Mameri, N., Taky, M., Nicolas, S., Elmidaoui, A. "Fluoride removal from brackish water by electrodialysis." Desalination. 133(3), pp. 215-223. 2001. https://doi.org/10.1016/S0011-9164(01)00102-3

[10] Ndiaye, P. I., Moulin, P., Dominguez, L., Millet, J. C., Charbit, F. "Removal of fluoride from electronic industrial effluent by RO membrane separation." Desalination. 173(1), pp. 25-32. 2005. https://doi.org/10.1016/j.desal.2004.07.042

[11] Sarkar, M., Banerjee, A., Pramanick, P. P., Sarkar, A. R. "Use of laterite for the removal of fluoride from contaminated drinking water." Journal of Colloid and Interface Science. 302(2), pp. 432-441. 2006. https://doi.org/10.1016/j.jcis.2006.07.001

[12] Maheshwari, R. "Fluoride in drinking water and its removal." Journal of Hazardous Materials. 137(1), pp. 456-463. 2006. https://doi.org/10.1016/j.jhazmat.2006.02.024

[13] Gupta, V. K., Ali, I., Saini, V. K. "Defluoridation of wastewaters using waste carbon slurry." Water Research. 41(15), pp. 3307-3316. 2007. https://doi.org/10.1016/j.watres.2007.04.029

[14] Venkata Mohan, S., Ramanaiah, S. V., Rajkumar, B., Sarma, P. N. "Removal of fluoride from aqueous phase by biosorption onto algal biosorbent Spirogyra sp.-IO2: Sorption mechanism elucidation." Journal of Hazardous Materials. 141(3), pp. 465-474. 2007. https://doi.org/10.1016/j.jhazmat.2006.07.008

[15] Venkata Mohan, S., Ramanaiah, S. V., Rajkumar, B., Sarma, P. N. "Biosorption of fluoride from aqueous phase onto algal Spirogyra IO1 and evaluation of adsorption kinetics." Bioresource Technology. 98(5), pp. 1006-1011. 2007.

https://doi.org/10.1016/j.biortech.2006.04.009

[16] Bhatnagar, M., Bhatnagar, A., Jha, S. "Interactive biosorption by microalgal biomass as a tool for fluoride removal." Biotechnology Letters. 24(13), pp. 1079-1081. 2002.

https://doi.org/10.1023/A:1016086631017

[17] Ramanaiah, S. V., Venkata Mohan, S., Sarma, P. N. "Adsorptive removal of fluoride from aqueous phase using waste fungus (Pleurotus ostreatus 1804) biosorbent: Kinetics evaluation." Ecological Engineering. 31(1), pp. 47-56. 2007.

https://doi.org/10.1016/j.ecoleng.2007.05.006

[18] Amin, F., Talpur, F. N., Balouch, A., Surhio, M. A., Bhutto, M. A. "Biosorption of fluoride from aqueous solution by white - rot fungus Pleurotus eryngii ATCC 90888." Environmental Nanotechnology, Monitoring \& Management. 3, pp. 30-37. 2015.

https://doi.org/10.1016/j.enmm.2014.11.003

[19] Illman, A. M., Scragg, A. H., Shales, S. W. "Increase in Chlorella strains calorific values when grown in low nitrogen medium." Enzyme and Microbial Technology. 27(8), pp. 631-635. 2000. https://doi.org/10.1016/S0141-0229(00)00266-0

[20] Safi, C., Zebib, B., Merah, O., Pontalier, P.-Y., Vaca-Garcia, C. "Morphology, composition, production, processing and applications of Chlorella vulgaris: A review." Renewable and Sustainable Energy Reviews. 35, pp. 265-278. 2014.

https://doi.org/10.1016/j.rser.2014.04.007
[21] Tsezos, M. "Adsorption by microbial biomass as a process for removal of ions from process or waste solutions." In: Immobilisation of Ions by Biosorption. (Eccles, H., Hunt, S. (ed.)), pp. 201-218, Ellis Harwood, Chichester. 1986.

[22] Aksu, Z., Gönen, F. "Biosorption of phenol by immobilized activated sludge in a continuous packed bed: prediction of breakthrough curves." Process Biochemistry. 39(5), pp. 599-613. 2004. https://doi.org/10.1016/S0032-9592(03)00132-8

[23] Aksu, Z., Gönen, F., Demircan, Z. "Biosorption of chromium(VI) ions by Mowital ${ }^{\circledR B} 30 \mathrm{H}$ resin immobilized activated sludge in a packed bed: comparison with granular activated carbon." Process Biochemistry. 38(2), pp. 175-186. 2002

https://doi.org/10.1016/S0032-9592(02)00053-5

[24] Texier, A. C., Andres, Y., Faur-Brasquet, C., Le Cloirec, P. "Fixed-bed study for lanthanide $(\mathrm{La}, \mathrm{Eu}, \mathrm{Yb})$ ions removal from aqueous solutions by immobilized Pseudomonas aeruginosa: experimental data and modelization." Chemosphere. 47(3), pp. 333-342. 2002.

URL: https://www.ncbi.nlm.nih.gov/pubmed/11996155

[25] Nagappa, B., Chandrappa, G. "Defluoridation of Bore Well Water Using Combustion Derived Nanocrystalline Magnesium Oxide." Transactions of the Indian Ceramic Society. 64(2), pp. 87-93. 2005. https://doi.org/10.1080/0371750X.2005.11012193

[26] Mythri, H., Dinesh, D. B. "Current public health perspective of fluorosis mitigation project in Pavagada taluk, Karnataka." Indian Journal of Occupational and Environmental Medicine. 16(3), pp. 124-126. 2012. https://doi.org/10.4103/0019-5278.111754

[27] Lim, S.-L., Chu, W.-L., Phang, S.-M. "Use of Chlorella vulgaris for bioremediation of textile wastewater." Bioresource Technology. 101(19), pp. $7314-7322.2010$

https://doi.org/10.1016/j.biortech.2010.04.092

[28] Costa, J. A. V., Linde, G. A., Atala, D. I. P., Mibielli, G. M., Krüger, R. T. "Modelling of growth conditions for cyanobacterium Spirulina platensis in microcosms." World Journal of Microbiology and Biotechnology. 16(1), pp. 15-18. 2000.

https://oi.org/10.1023/A:1008992826344

[29] Aksu, Z., Ãzer, D., Ãzer, A., Kutsal, T., Çaglar, A. "Investigation of the Column Performance of Cadmium(II) Biosorption by Cladophora crispata Flocs in a Packed Bed." Separation Science and Technology. 33(5), pp. 667-682. 1998.

https://doi.org/10.1080/01496399808544782

[30] Gabaldon, C., Marzal, P., Seco, A., Gonzalez, J. A. "Cadmium and Copper Removal by a Granular Activated Carbon in Laboratory Column Systems." Separation Science and Technology. 35(7), pp. 1039-1053. 2000. https://doi.org/10.1081/SS-100100209

[31] Mohamadinejad, H., Knox, J. C., Smith, J. E. "Experimental and Numerical Investigation of Adsorption/Desorption in Packed Sorption Beds under Ideal and Nonideal Flows." Separation Science and Technology. 35(1), pp. 1-22. 2000. https://doi.org/10.1081/SS-100100140

[32] Chen, N., Zhang, Z., Feng, C., Li, M., Chen, R., Sugiura, N. "Investigations on the batch and fixed-bed column performance of fluoride adsorption by Kanuma mud." Desalination. 268(1-3), pp. 76-82. 2011 https://doi.org/10.1016/j.desal.2010.09.053

[33] Nazari, G., Abolghasemi, H., Esmaieli, M., Sadeghi Pouya, E. "Aqueous phase adsorption of cephalexin by walnut shell-based activated carbon: A fixed-bed column study." Applied Surface Science. 375, pp. 144-153. 2016. https://doi.org/10.1016/j.apsusc.2016.03.096 
[34] Han, R., Wang, Y., Zhao, X., Wang, Y., Xie, F., Cheng, J., Tang, M. "Adsorption of methylene blue by phoenix tree leaf powder in a fixed-bed column: experiments and prediction of breakthrough curves." Desalination. 245(1), pp. 284-297. 2009. https://doi.org/10.1016/j.desal.2008.07.013

[35] Bohart, G. S., Adams, E. Q. "Some aspects of the behavior of charcoal with respect to chlorine." Journal of the Franklin Institute. 189(5), p. 669. 1920.

https://doi.org/10.1016/S0016-0032(20)90400-3

[36] Hutchins, R. A. "New method simplifies design of activated carbon systems." American Journal of Chemical Engineering. 80, pp.133-138. 1973.
[37] McKay, G., Bino, M. J. "Fixed bed adsorption for the removal of pollutants from water." Environmental Pollution. 66(1), pp. 33-53. 1990. https://doi.org/10.1016/0269-7491(90)90197-K

[38] Sarin, V., Singh, T. S., Pant, K. K. "Thermodynamic and breakthrough column studies for the selective sorption of chromium from industrial effluent on activated eucalyptus bark." Bioresource Technology. 97(16), pp. 1986-1993. 2006.

https://doi.org/10.1016/j.biortech.2005.10.001 